\title{
The primitive cable car (varangel) accident-related fatalities: A retrospective autopsy study
}

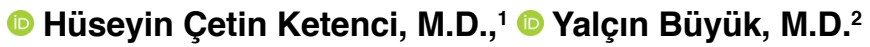

\author{
${ }^{1}$ Council of Forensic Medicine Branch of Trabzon, Trabzon-Turkey \\ ${ }^{2}$ Council of Forensic Medicine, İstanbul-Turkey
}

\begin{abstract}
BACKGROUND: The primitive cable car is the generic name given to the cable transportation settings driven between one or more steel cables is known as "varangel." In this retrospective autopsy study, it was aimed to discuss the common injury patterns of the fatalities associated with the use of these primitive cable car systems.
\end{abstract}

METHODS: It is a retrospective archive-based study. The analysis of autopsy records of 10 -year period between 2007 and 2016 revealed eight death cases resulting from the primitive cable car accident.

RESULTS: It was revealed that the primitive cable car-related deaths mainly occur because of blunt traumas (crash of cage, chit by the broken cables, and failing from height) and electric shock. The blunt traumas and failings from height occur because of contact with the cage of primitive cable car, whereas the electric shocks occur because of contact with cables, on which the cage is hung.

CONCLUSION: Primitive cable cars may be fatal and must be under official control.

Keywords: Autopsy; cable car; death; varangel.

\section{INTRODUCTION}

The cable car is the generic name given to the cable transportation settings driven between one or more steel cables extended between two distant points on the air. ${ }^{\left[{ }^{[}\right]}$It is known that the simple forms of cable car method have been seen in wall construction in China around 250 B.C. for the Ist time. ${ }^{[2]}$ Together with the advancements in industry and the invention of electricity, the cable cars have been improved throughout their own evolution and they have kept being used to date. Its modern forms are still in use for purposes such as winter sports, nature tourism, and other touristic purposes. The primitive forms of this system are used in various locations around the world, especially in rough and rural areas of Asia. ${ }^{[3-5]}$ These primitive cable cars are frequently used in Eastern Black Sea region in Turkey, where the present study was carried out. ${ }^{[4]}$

With the mountains and steep hills, the Eastern Black Sea Region of Turkey has a unique geographical structure. With mountainous coastline of $39,203 \mathrm{~km}^{2}(5.1 \%$ of the country) and population of 2.8 million ( 2018 census), the Eastern Black Sea Region of Turkey has the highest summits (above $3900 \mathrm{~m}$ ) in the central part of the region. ${ }^{[6]}$ Annual precipitation in the coastal regions ranges between 2000 and $2500 \mathrm{~mm}$ because of the dense forests in this region. The natural features in the Eastern Black Sea Region make it difficult to live in this region. In Eastern Black Sea Region, the agricultural areas and settlements are located far away, dispersed, and scattered. It is difficult to reach this area due to the distance from developed areas, as well as the insufficient infrastructure (Fig. I).

The tea and hazelnut plantations in this mountainous and rugged region constitute the main source of income for the inhabitants. ${ }^{[7]}$ It is very difficult to travel between the residential areas and agricultural lands. The mountainous zones in this region suffer from the lack of fundamental services such as transportation. This geographical structure of the region forces the people to search alternative transportation vehi-

Cite this article as: Ketenci HÇ, Büyük Y. The primitive cable car (varangel) accident-related fatalities: A retrospective autopsy study. Ulus Travma Acil Cerrahi Derg 2021;27:331-336.

Address for correspondence: Hüseyin Çetin Ketenci, M.D.

Trabzon Adli Tıp Grup Başkanlığı, Trabzon, Turkey

Tel: +90 462 - 3355555 E-mail: hcketenci@gmail.com

Ulus Travma Acil Cerrahi Derg 2021;27(3):33I-336 DOI: 10.14744/tjtes.2020.36485 Submitted: 28.04.2020 Accepted: 08.05.2020

Copyright 2021 Turkish Association of Trauma and Emergency Surgery 


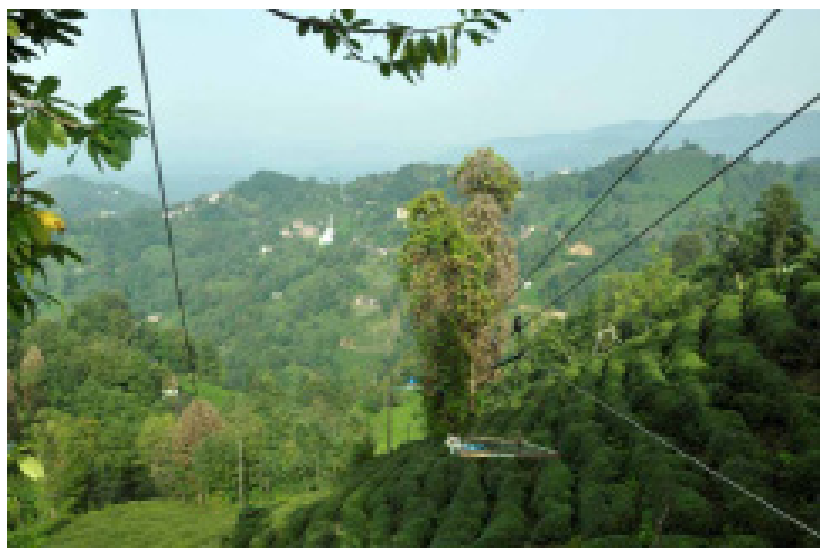

Figure 1. A typical view of the region including a varangel and its ropes.

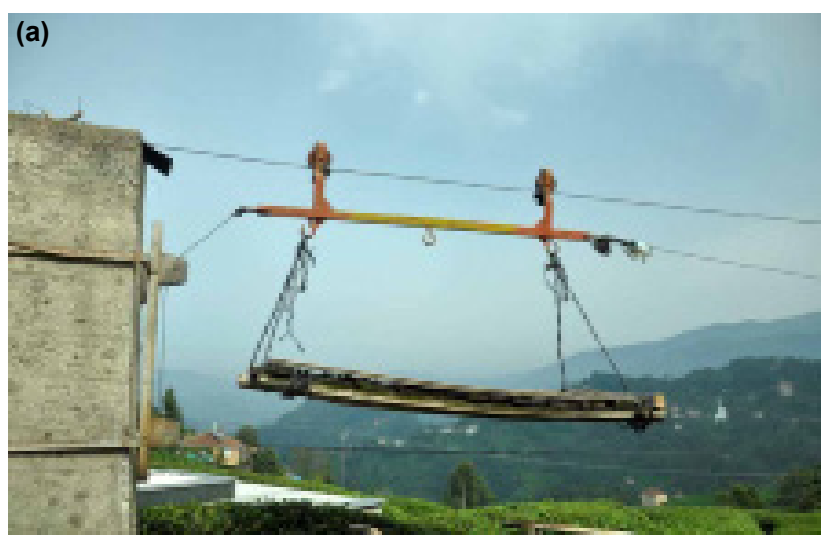

(b)

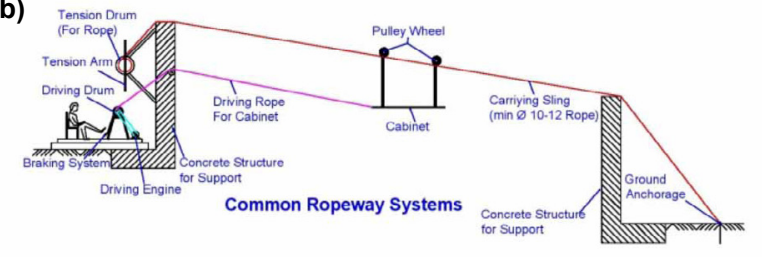

Figure 2. (a) Varangel. (b) A diagram of the varangel.

cles to reach the areas otherwise inaccessible by common means of transport. The local people living in this region have developed a cable car-like primitive vehicle called "varangel" (Fig. 2a and b). ${ }^{[8]}$

The electric engines are currently used in these simple devices for the ease of use. In the distant areas, the gasoline or diesel engines can be used because of the difficulty in access to electricity. ${ }^{[9]}$ The electricity need of these primitive devices is frequently met from the electricity networks of the houses through the electric cables. These cables constitute the main source of electrical accidents. The need of engine power is determined in accordance with the slope of the ground, the weight of load, and the transport direction of load (upward or downward), and it ranges between 2 and 10 horsepower (Fig. 3a). ${ }^{[10]}$ Two steel cables are stretched between two distant points and the transportation platform slides on these cables. The use of pulleys facilitates the slide of platform.
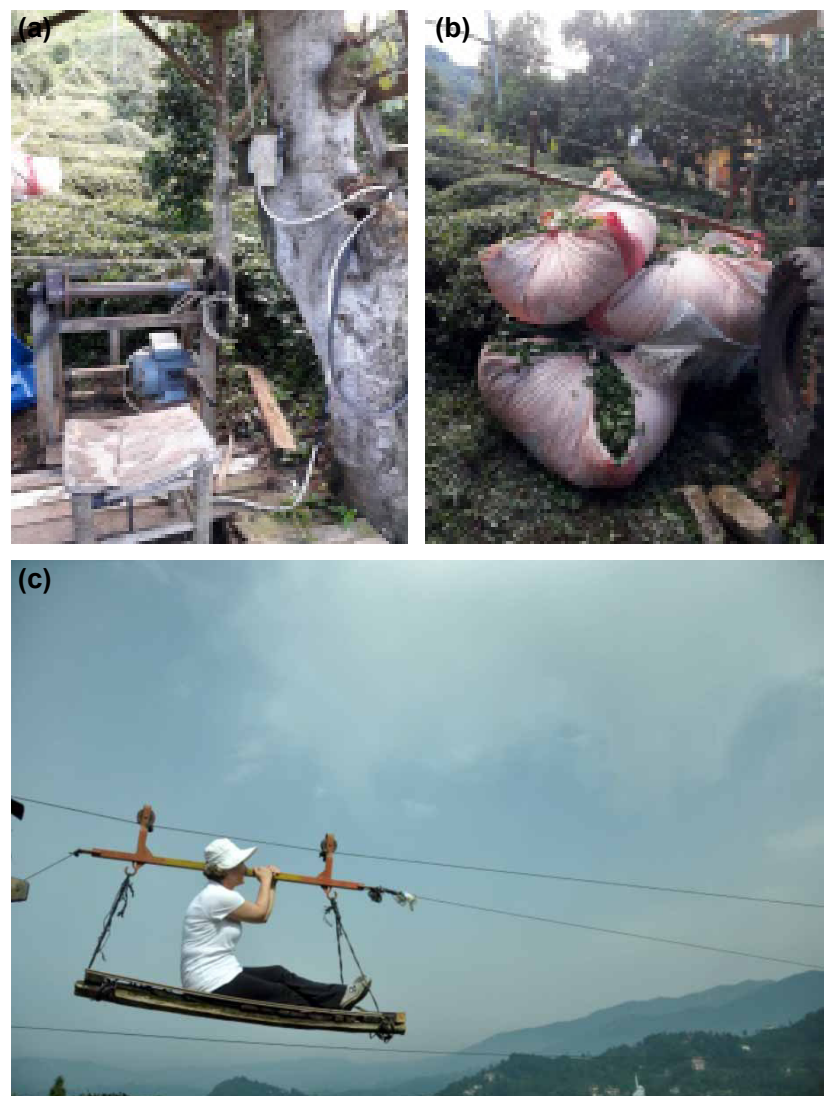

Figure 3. (a) Electrical system and engine of the varangel. (b) Heavy and unstable tea load on the varangel. (c) Human transportation with varangel.

It is estimated that approx. 20,000 varangels are in use throughout the Eastern Black Sea Region and almost 50\% of them are located in Rize Province. These varangels are used for crossing the rivers and valleys and traveling between the plantation areas and houses. Although it is prohibited by the local authorities, they are used for carrying not only the goods but also the passengers (Fig. $3 \mathrm{~b}$ and $\mathrm{c}$ ).

The primitive technology used in the assembly of these vehicles and the carelessness during the transportation process has resulted in devastating injuries and tragic deaths. In this retrospective autopsy study, it was aimed to discuss the common injury patterns of the fatalities associated with the use of these primitive cable car systems.

\section{MATERIALS AND METHODS}

In this retrospective descriptive autopsy study, the cases of death due to the primitive cable car accidents, which have been referred to Trabzon Regional Directorate of Council of Forensic Medicine (CFM) between 2007 and 2016 years, were investigated. Trabzon Directorate of CFM plays a central and reference role in medicolegal examination of suspicious deaths in Trabzon and other provinces of the region. Eight hundred and fifty autopsy procedures, 1000 microscopic examinations, 3500 toxicological analyses, and 700 forensic 
biological examinations (including the genetic examinations) are performed annually in this center.

The total number of autopsies performed during the 10 year study period was determined to be 8507 . Eight fatalities found in the study period were evaluated in terms of the parameters such as demographic characteristics (age, sex, nationality, and profession), year and month of the incident, the nature of load transported using the system, type of the accident, the responsible injury agent, the type, range and severity of traumatic findings, the presence of the signs of electrocution, the exact cause of death, and the toxicological and microscopic findings.

Descriptive statistics (number, percentages, median, min, and max) have been used to demonstrate the cases. The statistical analyses were performed using IBM SPSS 24 software.

\section{RESULTS}

The retrospective analysis of autopsy records of 10 -year period between 2007 and 2016 revealed eight death cases resulting from the primitive cable car accident. They constituted $0.094 \%$ of the total autopsy cases. There was only one female victim and the median age was calculated to be 43.5 years (min-max; 23 and 70 years, respectively).

Except for three Georgian citizens, all the other cases were Turkish. The majority of victims were workers in the tea and wood industries. There was one victim of "human transportation" by this primitive transport system. Table I shows the details of victims.

When these primitive system's parts causing the injuries were evaluated, it was determined that the cable of transporting system caused three injury cases, whereas falling from the cage of system caused injuries in three victims. The accident details and the trauma mechanisms are summarized in Table 2.

Intracranial hemorrhage was found to be the leading cause of death due to autopsy results. The autopsy findings and histopathology results are presented in Table 3.

\section{DISCUSSION}

The primitive cable cars pose death risk for the users. ${ }^{[1]}$ In the present study, it was revealed that the primitive cable car-related deaths mainly occur because of blunt traumas (crash

Table I. Descriptive characteristics of the victims

\begin{tabular}{lcccccccc}
\hline Case & Age (years) & Sex & Nationality & Month & Year & Province & Profession & Type of load \\
\hline Case I & 23 & Male & Georgian & July & $201 I$ & Trabzon & Worker & Tea \\
Case II & 70 & Male & Turkish & December & $201 I$ & Rize & Resident (Not worker) & Wood \\
Case III & 25 & Male & Georgian & September & 2012 & Trabzon & Worker & Tea \\
Case IV & 40 & Male & Turkish & January & 2013 & Artvin & Worker & Tea \\
Case V & $4 I$ & Male & Turkish & May & 2013 & Rize & Resident (Not worker) & Human \\
Case VI & 50 & Male & Georgian & July & 2013 & Rize & Worker & Tea \\
Case VII & 65 & Male & Turkish & September & 2013 & Artvin & Resident (Not worker) & Tea \\
Case VIII & 46 & Female & Turkish & May & 2016 & Rize & Worker & Tea
\end{tabular}

Table 2. Accident details and trauma mechanisms

\begin{tabular}{|c|c|c|c|}
\hline Case & Injury agent & Type of trauma & Details of the accident \\
\hline Case I & Transporting cable & Blunt trauma & $\begin{array}{l}\text { Impact of the transporting cable after tearing resulted in laceration of the scalp } \\
\text { and brain hemorrhage }\end{array}$ \\
\hline Case II & Fall from height & Blunt trauma & $\begin{array}{l}\text { Sudden movement of the cage resulted in falling of the person and brain } \\
\text { hemorrhage was the cause of death. }\end{array}$ \\
\hline Case III & Cage of the cable car & Blunt trauma & Impact of the cage to the worker waiting for the load resulted in severe head trauma. \\
\hline Case IV & Transporting cable & Electrocution & Electro shock by contact of the cable to high-voltage wires. \\
\hline Case V & Fall from height & Blunt trauma & Falling of the person during human transportation \\
\hline Case VI & Cage of the cable car & Blunt trauma & Impact of the cage to the worker waiting for the load. \\
\hline Case VII & Transporting cable & electrocution & Electro shock by contact of the cable to high-voltage wires. \\
\hline Case VIII & Cage of the cable car & Blunt trauma & Impact of the cage to the worker waiting for the load. \\
\hline
\end{tabular}


Table 3. Autopsy-histopathology results of the cable car accidents resulted in death

\begin{tabular}{|c|c|c|c|c|c|c|}
\hline Case & $\begin{array}{l}\text { Trauma } \\
\text { region }\end{array}$ & $\begin{array}{l}\text { Electric } \\
\text { entrance } \\
\text { region }\end{array}$ & $\begin{array}{l}\text { Bone } \\
\text { fracture } \\
\text { region }\end{array}$ & $\begin{array}{l}\text { Bluntly injured } \\
\text { organ }\end{array}$ & Pathology & Cause of death \\
\hline Case I & Head & No & Cranium & Brain & Hemorrhage, laceration & Intracranial hemorrhage \\
\hline Case 2 & $\begin{array}{l}\text { Head, neck, } \\
\text { foot }\end{array}$ & No & $\begin{array}{l}\text { Cervical } \\
\text { vertebra }\end{array}$ & Brain, & Hemorrhage, laceration & Intracranial hemorrhage \\
\hline Case 3 & Head & No & Cranium & Brain & Hemorrhage, laceration & Intracranial hemorrhage \\
\hline Case 4 & No & Elbow & No fracture & No blunt & Electric passage, heat effect & Electric shock \\
\hline Case 5 & $\begin{array}{l}\text { Chest, } \\
\text { femur }\end{array}$ & No & $\begin{array}{l}\text { Thoracic } \\
\text { cage }\end{array}$ & $\begin{array}{l}\text { Lung, liver, aorta, } \\
\text { pulmonary artery } \\
\text { and vein }\end{array}$ & Hemorrhage, laceration & $\begin{array}{l}\text { Visceral organ and } \\
\text { major vein damage }\end{array}$ \\
\hline Case 6 & $\begin{array}{l}\text { Head, } \\
\text { chest }\end{array}$ & No & Cranium & Brain, eye & Hemorrhage, laceration & $\begin{array}{l}\text { Intracranial hemorrhage, } \\
\text { pneumothorax, }\end{array}$ \\
\hline Case 7 & No & Hand & No fracture & No blunt & Electric passage, heat effect & Electric shock \\
\hline Case 8 & $\begin{array}{l}\text { Chest, upper } \\
\text { extremity }\end{array}$ & No & $\begin{array}{c}\text { Thoracic } \\
\text { cage }\end{array}$ & $\begin{array}{l}\text { Lung, liver, spleen, } \\
\text { thoracic aorta }\end{array}$ & Hemorrhage, laceration & $\begin{array}{l}\text { Visceral organ and major vein } \\
\text { damage, internal hemorrhage }\end{array}$ \\
\hline
\end{tabular}

of cage, chit by the broken cables, and failing from height) and electric shock. The blunt traumas and failings from height occur because of contact with the cage of primitive cable car, whereas the electric shocks occur because of contact with cables, on which the cage is hung.

Within this context, given the fact that two of the cases discussed in the present study occurred because of failing from primitive cable car, the attention should be paid to the geographical structure of the region, the character and weight of the load being carried, the slope between two main posts, and the presence of any obstacle along the line such as trees or tree branches in relationship with the type of planned task. Moreover, no living creature, especially the humans, should be transported using the primitive cable cars. In case of a necessity, the cable car's cage should be closed and safe in accordance with the relative regulations. Thus, the deaths caused by the failing from height should be minimized. There are legal regulations related with the production and operation of cable cars designed for human transportation. ${ }^{[1]}$

In the present study, the deaths caused by the wrapped wire were found. Two of them were related with electric shock and one was related with head trauma because of the rupture of wire. It should be noted that, as many metals, the wire cables are also exposed to fatigue under repetitive loads. Moreover, the negative conditions due to the corrosions because of inappropriateness of material being used or the flow or even rupture because of heavy loads make these cables unusable. ${ }^{[12]}$ The cables should be lubricated regularly to prevent the problems that may occur due to the corrosion of cables in the course of time or the problems that may arise due to the friction. This lubrication should be performed using high-quality lubricants. ${ }^{[13]}$ For these reasons, attention should be paid to the mechanical properties of cables and the material characteristics during the design process. Besides that, the safety conditions should also be met. There are various specifications on this subject throughout the world. According to these specifications, the selection of cables is an important factor for the safety. ${ }^{[14,15]}$

In literature, no study examining the deaths because of primitive cable car accident was found. Besides that, in addition to the injuries that have also been examined in the previous studies, the present examines the reasons for death. The reasons for death analyzed in this study were found to be similar to the reasons for injuries reported in literature. The most frequently seen reasons for death were found to be various blunt or other traumas as a result of falling down because of stuck clothes or body parts to the cage, hanging in the air

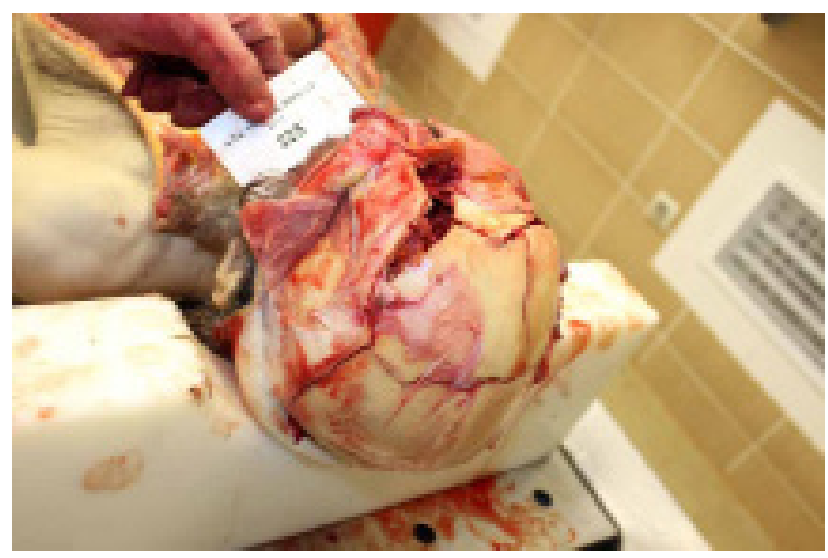

Figure 4. Skull fracture because of varangel crush. 
or falling from height, the electric shocks seen especially in wet weather conditions, and the crush of cage to the person waiting for the load. ${ }^{[7,8]}$ In the present study, it was determined that, for the death cases, especially the blunt traumas in the head region caused intracranial hemorrhage and the death occurred (Fig. 4). To prevent such type of crush caused deaths, it is very important for the loader operating the primitive cable car at that moment and the person waiting for unloading the load to keep in communication with each other. To ensure this, as the local people frequently apply, the person releasing the load from high should hit the wires using a hard material. Since the sound moves faster than the load along the wire, the person waiting for the load can ensure his/her safety. Given the death cases examined in the present study, it is attention grabbing that the Georgian workers, who are relatively stranger to this practice, died because of blunt traumas. This important application should be taught to the workers, who have come from abroad, before operating the cable car system.

The primitive cable cars are generally operated electrically. ${ }^{[10]}$ Given the cases, the electric shocks draw attention. These cases generally occurred because of the factors such as the electric leakage occurring because of the wear of the electric cables illegally pulled from the houses, the leakages from the engines used, and the cables becoming closer to the high-voltage lines during the movement of cable car. Besides them, the precipitation due to the climate conditions of the region is a factor increasing the risk.

It was observed that the primitive cable cage accidents generally occurred because of the user errors and the neglecting the periodical controls. The most significant user errors are to transport living beings in the cable car, the unbalanced loads, being stuck to the moving cabin, hook or wire, operating the loaded cabin without informing the person waiting for that cabin, and the use of primitive cable car system by the young people for entertainment or taking photos. Within this context, two of eight cases occurred because of falling from height, whereas all the other cases (except for one case) occurred while transporting wood and tea plant.

The users have no license or training. Since there is no license for primitive cable cars, the periodical maintenances and the official tests are not performed. However, when called by the owners of these systems, the producers or craftsmen experienced in this subject perform the repairs and controls.

\section{Limitations}

Despite the frequency of use and the presence of approx. 20,000 primitive cable cars in use, it can be said that the number of accidents and deaths is relatively low. ${ }^{[16]}$ Some of the reasons for this is that the primitive cable cars have been used in the region for long time and the users are relatively familiar to this mechanism. In the present study, only the death cas- es were examined. It is expected that the injuries that have occurred but not resulted in death are much higher. Moreover, in deaths occurring because of the primitive cable car accidents, the events might be considered as a normal death under local conditions and the funeral procedures might be carried out without conveying to the legal authorities. This may be another reason for finding only eight death cases during 10 -year period examined in this study.

\section{Conclusion}

The present study is the first study on this subject in the forensic medicine literature. It is reported in the present study that the primitive cable cars cause accidents that may result in death. The prominent reasons for death are the intracranial hemorrhage because of blunt traumas and falling from height and the major vein damages.

The below-mentioned measures should be taken to prevent them. Placing the engine of cable car within a cabin and taking the engine and drivetrains under protection within a protective shelter, keeping the door of engine cabin closed/locked when not using or when operator is not there, having the key held only by the responsible person, not allowing the system to be used by anyone other than the responsible person, meeting the standards for lighting, air ventilation, electrical panel, and break mechanism of engine, maintenance and controls of wires, pulleys, winding drum, and break, controlling the diameter decreases and broken fibers in the lines, isolation of the power line, not transporting any living creature (animal or human), taking measures to ensure the balance of load and to prevent falling, ensuring that only the authorized persons respond to the failures, fixing the posts (the protective mechanism at the departure and arrival points of the platform) appropriately to the ground and supporting these posts using materials (such as rubber) that can absorb the impact of load platforms, following the annual controls, obtaining the conformity document for load transport, and tight control by the government.

\section{Acknowledgment}

We are thankful to Council of Forensic Medicine - Turkey because of the approval of the study.

Ethics Committee Approval: This study was conducted by T.C. Approved by the Forensic Medicine Institute of the Ministry of Justice (31.01.2017-21589509/63).

Peer-review: Internally peer-reviewed.

Authorship Contributions: Concept: H.Ç.K.; Design: H.Ç.K.; Supervision: Y.B.; Resource: H.Ç.K.; Materials: H.Ç.K.; Data: H.Ç.K.; Analysis: H.Ç.K.; Literature search: H.Ç.K.; Writing: H.Ç.K.; Critical revision: Y.B., H.Ç.K.

Conflict of Interest: None declared.

Financial Disclosure: The authors declared that this study has received no financial support. 


\section{REFERENCES}

1. Cerit D. Teleferik sistemleri. Elektrik Mühendisleri Odası İzmir Şubesi Haber Bülteni. Vol. 254. 2011.p. 34-7.

2. Demirsoy M, Demirsoy M. Teleferik ve Telesiyej Tekniği (Halatla İletim Tekniği). Available from: http://www.emo.org.tr/ekler/5d592df9b8cd13a_ek.pdf. Accessed Sep 24, 2019.

3. Intermediate Technology Development Group. Aerial Ropeway in Nepal. Available from: http://www.library.uniteddiversity.coop/Ecological_Building/aerial_ropeway.pdf. Accessed Sep 24, 2019.

4. Ozlu T, Caglak S, Samlioglu H. Cable Car installation and the impact of its usage on social life and economy in the Ardeșen (Rize) region. J Int Soc Res 2014;7:350-64.

5. Shambhu DB. Gravity ropeway: Could be a reliable source of transport the goods and services in hills and mountainous region of Nepal. Stuttgart, Germany: 6th International Symposium Networks for Mobilitiy, 27-28 Sep. 2012.

6. Türkiye İstatistik Kurumu. Available from: http://tuik.gov.tr/PreTablo. do?alt_id=1027. Accessed Sep 24, 2019.

7. Gunduz A, Turedi S, Topbas M, Tekinbas C, Nuhoglu I. Primitive transport vehicle (varangele) accidents.] Emerg Med 2009;36:402-03. [CrossRef]
8. Bilir O, Ersunan G, Balik MS. Primitive cable car "varangel” accidents in the black sea region of Rize in Turkey. J Exp Clin Med 2016;33:63-8.

9. Ministry of Environment and Forest, Government of India. Environmental impact assessment guidance manual for aerial ropeways. Hyderabad: Administrative Staff College of India; 2010. p. 4-42.

10. Demirsoy M, Demirsoy M. Teleferik tesislerinde kullanilan elemanlar. İzmir, Turkiye: Asansör Sempozyumu, 23-25 May; 2008.

11. Resmi Gazete. Available from: http://www.resmigazete.gov.tr/eskiler/2005/01/20050119-10.htm. Accessed May 08, 2019.

12. Shinde VV, Arora KC. Aspects of materials handling. New Delhi: Laxmi Publications; 2015.

13. Demirsoy M. Transport Tekniği. İstanbul, Türkiye: Birsen Yayınevi; 1993.

14. Türk Standardı, TS EN 1709. İnsan taşımak için tasarımlanan halatlı hat tesisleri için güvenlik kuralları işletmeye alma öncesi muayene, bakım, işletme ile ilgili muayene ve kontroller; 2005.

15. Türk Standardı, TS EN 13796-1. İnsan taşımak için tasarımlanmış halatlı tesislerin güvenlik kuralları-taşıyıcılar; 2017.

16. Türk Mühendis ve Mimar Odaları Birliği. Available from: http://www. mmorize.org/mmo_rize_haber10.htm. Accessed Sep 12, 2019.

\section{ORİJINAL ÇALIŞMA - ÖZET}

\section{İlkel teleferik (varangel) kazaları ile ilişkili ölümler: Geriye dönük otopsi çalışması \\ Dr. Hüseyin Çetin Ketenci, ${ }^{1}$ Dr. Yalçın Büyük ${ }^{2}$ \\ ${ }^{1}$ Trabzon Adli Tıp Grup Başkanlığı, Trabzon \\ ${ }^{2}$ Adli Tıp Kurumu Başkanlığı, İstanbul}

AMAÇ: Illkel teleferik, iki sabit nokta arasında; gerilmiş kalın bir ana tel üzerindeki makara vasıtasıyla, tele asılı haldeki bir kabinin başka bir tel ve motor yardımıyla hareket ettirilmesi prensibine dayanan basit düzeneğe verilen genel bir isimdir ve "varangel" olarak da bilinir. Bu geriye dönük otopsi çalışmasında, ilkel teleferik sistemlerinin kullanımı ile ilişkili ölüm mekanizmalarının ve nedenlerinin tartışılması amaçlanmıştır.

GEREÇ VE YÖNTEM: Geriye dönük arşiv çalışmasında; 2007-2016 yılları arasındaki 10 yıllık otopsi kayıtlarının analizi, ilkel teleferik kazasından kaynaklanan sekiz ölüm vakasını ortaya çıkarmıştır.

BULGULAR: İlkel teleferikle ilgili ölümlerin esas olarak künt travmalar (kabinin çarpması, yüksekten düşme) ve elektrik çarpması sonucunda oluştuğu saptanmıştır. Künt travmalar ve yüksekten düşmeler ilkel teleferik kabininden kaynaklanırken, elektrik çarpmaları; kabinin asıldığı kablolara temastan meydana gelmiştir.

TARTIŞMA: Çalışma ilkel teleferiklerle ilgili kazaların ölümle sonuçlanabileceğini göstermiştir. Kıııtlı bir bölgede, yaygın olarak kullanılan bu düzeneğin kullanım kurallarının ve periyodik takiplerinin, belirlenecek prosedürlerle kontrol altına alınması bu konudaki ölümlerin azaltılmasında fayda sağlayabilir.

Anahtar sözcükler: Otopsi; ölüm; teleferik; varangel.

Ulus Travma Acil Cerrahi Derg 2021;27(3):33I-336 doi: 10.14744/tjtes.2020.36485 